\title{
Urban Disaster Recovery in Christchurch: The Central Business District Cordon and Other Critical Decisions
}

\author{
Stephanie E. Chang, ${ }^{\text {a) }}$ M.EERI, Josh E. Taylor, ${ }^{\text {a) }}$ Kenneth J. Elwood, ${ }^{\text {b) }}$ \\ M.EERI, Erica Seville, ${ }^{c)}$ Dave Brunsdon, ${ }^{\text {d) }}$ M.EERI, and Mikaël Gartner ${ }^{\mathrm{e}}$
}

The Canterbury earthquakes, which involved widespread damage in the February 2011 event and ongoing aftershocks near the Christchurch central business district (CBD), presented decision-makers with many recovery challenges. This paper identifies major government decisions, challenges, and lessons in the early recovery of Christchurch based on 23 key-informant interviews conducted 15 months after the February 2011 earthquake. It then focuses on one of the most important decisions maintaining the cordon around the heavily damaged CBD - and investigates its impacts. The cordon displaced 50,000 central city jobs, raised questions about (and provided new opportunities for) the long-term viability of downtown, influenced the number and practice of building demolitions, and affected debris management; despite being associated with substantial losses, the cordon was commonly viewed as necessary, and provided some benefits in facilitating recovery. Management of the cordon poses important lessons for planning for catastrophic urban earthquakes around the world.

\section{Full citation:}

Chang, S. E., Taylor, J. E., Elwood, K. J., Seville, E., Brunsdon, D., \& Gartner, M. (2014). Urban Disaster Recovery in Christchurch: The Central Business District Cordon and Other Critical Decisions. Earthquake Spectra. doi: 10.1193/022413EQS050M. http://earthquakespectra.org/doi/abs/10.1193/022413EQS050M

COPYRIGHT (2014) EARTHQUAKE ENGINEERING RESEARCH INSTITUTE. THIS ARTICLE MAY BE DOWNLOADED FOR PERSONAL USE ONLY. ANY OTHER USE REQUIRES PRIOR PERMISSION OF THE EARTHQUAKE ENGINEERING RESEARCH INSTITUTE

\footnotetext{
a) School of Community and Regional Planning, 242-1933 West Mall, University of British Columbia, Vancouver, BC V6T1Z2, Canada

b) Department of Civil Engineering, University of British Columbia, 6250 Applied Science Lane, Vancouver, BC V6T1Z4, Canada

c) Risk Strategies Research and Consulting, 219 Wyndale Rd, RD1, Sheffield, 7580, New Zealand

d) Kestrel Group Ltd., 114 Lambton Quay, PO Box 5050, Wellington, New Zealand

e) Canterbury Earthquake Recovery Authority (CERA), 62 Worcester Blvd, Christchurch, New Zealand 8140
} 


\section{INTRODUCTION}

The Canterbury Earthquake Sequence has impacted all aspects of the natural, built, and social environments around Christchurch, New Zealand, a city of approximately 375,000. The most significant events in the sequence, in terms of impacts, occurred on 4 September 2010 (M 7.1), 26 December 2010 (M 4.7), 22 February 2011 (M 6.3), 13 June 2011 (M 6.0) and 23 December 2011 (M 5.9). Of these events, the most significant impacts on the city of Christchurch occurred on 22 February 2011 when two multi-story concrete office buildings collapsed and hundreds of unreinforced masonry buildings experienced partial or total collapse, resulting in 182 confirmed deaths. Many other buildings in the Central Business District (CBD) experienced severe damage, many requiring demolition. The February 2011 earthquake resulted in the first ever National Declaration under the Civil Defence Emergency Management Act. The direct costs from the February event are estimated at 16 billion NZD or $13 \%$ of New Zealand GDP (CATDAT 2011), while the total costs including indirect impacts are expected to be considerably higher.

Challenges must be faced and key decisions made following an earthquake disaster. For the Canterbury earthquakes, some of the challenges included how to manage public safety in the face of substantial building damage, how to provide guidance for rebuilding and repairs, and who should manage the complex recovery process. Similar challenges will be faced in other earthquake-prone regions and the Canterbury earthquakes provide an important opportunity to learn from the decisions made and their consequences for recovery. The similarity of the New Zealand built environment and societal structure with other western countries makes the Canterbury earthquakes particularly relevant for post-earthquake planning and decision-making in North American cities.

This study sought to identify and explore the most important decisions - especially government decisions - influencing the early recovery of Christchurch in the first 15 months after the February earthquake. Following a section describing the methodological approach, the paper presents overall findings on key decisions, challenges, and lessons. The paper then focuses on an in-depth discussion of one of these key decisions - cordoning the CBD - and its impacts. The Conclusions section discusses the significance of the findings for other earthquake-prone urban areas. 


\section{METHODOLOGICAL APPROACH}

The research team conducted 23 semi-structured, key informant interviews to gather data on major decisions, decision-making processes, context, and impacts. The interviewees were selected on the basis of either their professional decision-making roles in the earthquake response and recovery or their roles as representatives of groups affected by recovery-related decisions. The interviewees (listed in Appendix A) included the National Controller in the Ministry of Civil Defence, the Chief Executive of the Canterbury Earthquake Recovery Authority (CERA), managers and engineers in various levels of government (CERA, Christchurch City Council, national Department of Building and Housing), insurance industry leaders, and representatives of community, business, and heritage groups.

All of the interviews were conducted during May 2012, 15 months after the February 2011 event. All interviews were conducted in-person in Christchurch and Wellington (except for one by videoconference and one in Vancouver, Canada). The interview questions were sent to the interviewees in advance. The interviews, which typically lasted 60 90 minutes, were audio-recorded with permission and transcribed. Interviews were conducted primarily by the Canadian research team (Chang, Elwood, Taylor); in most of the interviews, at least one of the New Zealand researchers (Seville, Brunsdon) also participated.

Interview questions (listed in Appendix B) focused on the respondents' perspectives on key decisions and their impacts on recovery. All of the key informants were asked about their own roles in earthquake response and recovery, how well they considered Christchurch's recovery to be proceeding, what they would identify as the three most important decisions influencing the recovery (not limited to their area of expertise), what they considered to be the most important recovery challenges going forward, and what lessons the disaster had provided in terms of recovery-related decision-making. Those interviewees who were considered decision-makers were also asked to focus on one of the following four areas (i.e., the one that they were most familiar with): establishment and maintenance of the Central Business District cordon; residential land zoning in the suburbs; building standards and assessment; and insurance. Within the focus area, decision-maker interviewees were asked to describe and discuss the most important decisions, including decision-making processes and unintended consequences. Interviewees who were not considered decision-makers for purposes of this study (e.g., community group representatives) were asked instead to identify and discuss the three most important decisions affecting their constituents. 
General findings are discussed in the next section. Throughout, this paper maintains a reference timeframe of 15 months following the February 2011 earthquake to ensure consistency between the interview data and the discussion of findings.

\section{KEY RECOVERY DECISIONS, CHALLENGES, AND LESSONS}

This section reviews findings from three areas covered in the interviews: how interviewees assessed recovery progress, what decisions were identified as the most critical, and the greatest challenges going forward. (For further details on the interviews and findings, see Taylor et al. 2012.)

\section{RECOVERY PROGRESS}

Interviewees were asked to rank how well they considered Christchurch's recovery to be proceeding, on a scale of 1-7, with 1 being "extremely poorly” and 7 being "extremely well." Recovery was not defined a priori; rather, interviewees were asked to rate recovery and then elaborate on their reasons (e.g., describing what full recovery would mean to them). The average score was a 4.2, and most interviewees stressed that they believed the recovery was proceeding as well as it could, given the size of the event relative to the GDP of New Zealand, and the number of earthquakes. Several respondents highlighted the unequal impact of the earthquakes geographically, and that how well recovery is proceeding "depends on where you live” (with west of CBD recovering much faster than east of the CBD).

For exploratory analysis, interviewees were grouped into four categories by their proximity to decision-making (Figure 1). Firstly, those who were directly involved in making decisions, secondly, those who were involved primarily as implementing those decisions, and thirdly, those who were impacted by those decisions. Interviewees involved with insurance were seen as a unique group in decision-making, and were included as a fourth group.

Interestingly, in the first three groups, interviewees closer to decision-making ranked progress higher. As shown in Figure 1, the average response from decision-makers was a 5.0, while the implementers provided an average score of 4.5, and community and business groups reported an average score of 3.9. These disparities confirm the importance of interviewing members of all the groups when exploring key recovery decisions and their impacts. Interviewees speaking on the topic of insurance ranked progress even lower, when benchmarking to other international examples. Insurance interviewees cited several unique features to the event that have affected the insurance industry. These include the number of 
earthquakes, pre-existing complexities built into insurance contracts, and the dual EQCprivate insurer model (see Brown et al., 2013; King et al., 2014).

\section{CRITICAL DECISIONS}

Interviewees were asked to identify the three most important decisions for recovery, made since February 2011. Respondents were not given a list of decisions, and responses varied widely, but three decisions did emerge as the most critical to recovery.

The early establishment by Central Government of a recovery agency, the Canterbury Earthquake Recovery Authority (CERA), was cited as the most important decision by a significant margin. ${ }^{1}$ Of the 23 interviewees, 18 , or about $80 \%$, ranked this decision in their top three. Specific aspects of the agency, such as having its own minister and being empowered to expedite the demolition of buildings, were also highlighted as being critical. Several respondents did raise questions as to the structure of CERA and whether a layer of governance should have been included between the Chief Executive and the Minister.

Residential zoning and the decision of the Government to buy-out several thousand homes on the worst liquefaction-affected land (see Williams et al. 2014) emerged as a distant second with nine interviewees ranking this decision in their top three. The buy-outs have created certainty for a large number of people, however there have been issues with the purchase price and the timelines of the process. Initially, 10,000 properties were classified as “orange zone”, awaiting further geotechnical study. Reclassifying all of these properties into red (for buy-out) or green (no buy-out) took longer than estimated and caused significant stress for those in the orange zone.

The third most-cited decision was to maintain the cordon around the CBD for an extended period of time. This decision, its consequences, and its benefits will be discussed in detail later in this paper.

\section{KEY CHALLENGES}

Respondents were asked to identify what they saw as the most important challenges to the recovery of Christchurch going forward. While responses were a mix of professional and personal opinions on different aspects of the recovery, four dominant themes emerged.

\footnotetext{
${ }^{1}$ CERA was responsible for developing an overall recovery strategy for the city, while the Christchurch City Council was initially tasked to develop a recovery plan for the central city - a role later brought back into CERA with the set-up of the Central City Development Unit (CCDU).
} 
Capital flight (i.e., assets or money rapidly leaving the city) was highlighted as a significant challenge for Christchurch. The high degree of insurance penetration means that many commercial buildings owners have the option of cashing out their capital investments and moving their money elsewhere in New Zealand, or internationally. The creation of the Christchurch Central Development Unit (CCDU) within CERA to manage the downtown rebuild was seen as critical, both in creating certainty with the siting of major public structures, and in creating an investment-friendly central city. In the near-term, generating competitive returns for capital invested in downtown Christchurch was seen as a significant challenge.

Insurance-related issues emerged as a major concern in the recovery going forward, particularly in terms of the complexity and time associated with settling insurance claims, as well as uncertainty around the future affordability of insurance. As mentioned previously, the number of earthquakes and the interaction between New Zealand's public insurance scheme, the Earthquake Commission (EQC), and private insurers have added to the complexity and length of settling claims.

Social dislocation created by the earthquakes was also reported as a significant challenge to the recovery. The impact of the earthquakes had varied widely across the city, and while some have been living in undamaged houses (generally to the west of the CBD), others in the eastern suburbs have been living in damaged houses with no working toilet, unsure as to their future, for over a year (at the time of this study). It is expected that housing repairs could take several years to be completely finished. The long-term impact for families and children growing up in these areas was cited as a significant challenge going forward. Attracting and retaining families in general were also reported as challenges. As of May 2012, many of Christchurch's schools were in temporary locations or working in off-hours, and many public amenities such as pools were closed. The city is also preparing for a major influx of temporary workers, and at this point the long-term social impacts of the earthquakes remain to be seen.

Building regulation changes following the September and February earthquakes have resulted in further challenges for the recovery of the built environment. The New Zealand Building Act defines an earthquake-prone building as a building that has a lateral strength less than 33\% of that required for a new building. The Act requires Territorial Authorities (e.g. local governments) to develop a policy on the identification and strengthening of 
earthquake-prone buildings. Prior to the 2010 September earthquake, the Christchurch City Council had adopted a passive approach, whereby earthquake-prone buildings were identified but retrofits would typically only be required with a change of use or significant modifications, and a building could be deemed not earthquake-prone by raising the lateral strength above the 33\% limit, although many informed owners opted to retrofit to higher than the minimum 33\% of current code. After the September earthquake, the Christchurch City Council changed the earthquake-prone building policy such that the target strengthening level was explicitly stated to be $67 \%$ of current code (CCC 2010). ${ }^{2}$ This applied to all earthquakeprone buildings, damaged or undamaged by the September earthquake, and hence applied to all structural repairs following the earthquake. The goal-posts changed again after the February earthquake when it was assessed that the Canterbury region would likely see an increased level of seismicity over an extended period of approximately 50 years. To address this increased risk, in May 2011, the seismic hazard factor used in the New Zealand building code was raised from 0.22 to 0.3 for the Canterbury region, effectively raising seismic design forces by 35\%. The combination of these two changes meant that the target strengthening level for a seismic retrofit in Christchurch increased by 270\% between September 2010 and May 2011. These "changing goal-posts” have further complicated insurance settlements as owners want insurance to cover repairs to damaged buildings that would bring the building in compliance with the new earthquake-prone building policy, while the insurance companies have objected since the new policy was not in place at the time the policy was enacted.

\section{CORDONING THE CENTRAL BUSINESS DISTRICT}

In order to further explore these key decisions, impacts, and recovery themes, this section provides an in-depth discussion of one of the key decisions, the cordoning of the $\mathrm{CBD}^{3}$. As noted above, the CBD cordon emerged as one of the three most significant decisions in recovery, along with the establishment of CERA and the residential zoning. The CBD cordon provides a valuable focus because it demonstrates the role of CERA in recovery and encompasses the key challenges of capital flight, insurance, social dislocation, and building regulations and standards. Furthermore, the cordon is of great interest because it represents a

\footnotetext{
${ }^{2}$ A decision by the High Court of New Zealand in December 2012, in response to an application for a judicial review brought by the Insurance Council of NZ, ruled that this aspect of the policy was not enforceable (The Insurance Council of NZ Inc v Christchurch City Council, 2013).

3 The CBD is considered here as the area bounded by the "four avenues" (Bealey, Fitzgerald, Deans, and Moorhouse Avenues), or the extent of the initial post-February earthquake cordon (see Figure 2). This initial cordon area encompassed 387 hectares; by August 2012, it had been reduced to 49 hectares (Brownlee, 2012).
} 
disaster management strategy that, while unprecedented in scale and duration, could potentially be implemented in other earthquake-affected cities around the world.

This section first describes the decisions to establish and maintain the CBD cordon, then discusses the impacts of the cordon. It considers the short-term impacts to businesses and potential longer-term impacts on viability of the urban core, as well as other, less evident impacts on the process of reconstruction and recovery. This section is based primarily on data from the key informant interviews (see Methodological Approach, above).

\section{ESTABLISHMENT AND MAINTENANCE OF THE CORDON}

\section{Context of Damage Concentration}

Christchurch, the second-largest city in New Zealand and the largest on the South Island, had a CBD prior to the Canterbury earthquakes that consisted of a small number of office towers located amidst a large expanse of low-rise commercial buildings and some residential stock. Located in the area of the original town settlement (established by Royal Charter in 1856), the urban area retained numerous unreinforced masonry (URM) and other older buildings, including some 930 buildings with designated heritage status (NZHPT, 2012). Approximately 6,000 businesses employing 50,000 workers were located in the CBD, accounting for approximately 25\% of the city’s employment (EERI, 2011). The Cathedral and Cathedral Square provided a focal point for tourism activities. The CBD had been declining prior to the earthquake, with high rates of underutilized or unused space (especially in older buildings above ground-floor retail stores), a sprawling physical footprint, and in some areas, problems of "anti-social” youth. Up to $40 \%$ of the available floorspace in the central city may have been unoccupied prior to the earthquakes. While some seismic retrofits had been undertaken, because of the pervasiveness of earthquake insurance ${ }^{4}$, some interviewees suggested that the local culture was one of insuring for loss rather than of investing in mitigation.

The extensive damage that occurred in the February 2011 earthquake can be attributed to the coincidence of this concentration of highly vulnerable structures (URM) with other factors, including the shallow rupture, near-field location of the epicenter, and preceding earthquakes (especially in September and December 2010) that damaged many buildings

\footnotetext{
${ }^{4}$ Swiss Re has indicated that $80 \%$ of losses from the earthquake sequence comprised insured losses (King et al 2014). One business survey following the September 2010 earthquake found that only 3\% of businesses did not have any form of insurance (e.g., property, business continuity) (Stevenson et al., 2011b).
} 
prior to the February event. The 4 September 2010 earthquake had caused structural damage to 290 heritage buildings, including many in the CBD area, and 84 of these were determined to be structurally unsound (NZHPT, 2012). In the CBD overall, some 26\% of buildings were initially tagged either red (unsafe) or yellow (restricted access) during preliminary assessments after the September earthquake (Stevenson et al., 2011b). In the February 2011 earthquake, building damage in CBD was considerably worse than September 2010, with $24 \%, 23 \%$, and $53 \%$ of CBD buildings tagged red, yellow, and green, respectively (Kam et al., 2011). Christchurch City Council has estimated that $40 \%$ of the City's heritage buildings were severely damaged in the February earthquake and subsequent aftershocks through June 2011 (NZHPT, 2012). Near the Avon River, liquefaction led to irregular settlement of several buildings.

Of the approximately 2,000 commercial buildings in the CBD, it appears that more than $50 \%$ may eventually be demolished as a consequence of the earthquakes. The Canterbury Earthquake Recovery Authority (CERA) estimates that at least 627 commercial buildings will be demolished in the CBD, of which 539 have already been torn down as of May 2012 (Table 1); the numbers are higher if partial demolitions and “make safe” works are included. The remainder, including many buildings over 10 stories, are expected to be demolished over the next 12 18 months. Nearly half of the approximately 220 buildings over 5 stories high in the CBD have been confirmed for demolition.

Table 1. Status of Commercial Building Demolitions at time of interviews (May 2012) ${ }^{(1)}$

\begin{tabular}{|l|c|c|c|}
\hline Location & \multirow{2}{*}{$\begin{array}{c}\text { No. Buildings } \\
\text { Confirmed for } \\
\text { Demolition }\end{array}$} & \multicolumn{2}{|c|}{$\begin{array}{c}\text { Demolitions Completed } \\
\text { as of May 2012 }\end{array}$} \\
\cline { 3 - 4 } & No. buildings & Percent \\
\hline Central Business District & 627 & 539 & $86.0 \%$ \\
\hline Suburbs & 290 & 239 & $82.4 \%$ \\
\hline Total & 917 & 778 & $84.8 \%$ \\
\hline
\end{tabular}

Notes: (1) Source: C. Devereux, Canterbury Earthquake Recovery Authority, correspondence June 7, 2012. Numbers do not include partial demolitions or "make safe” works.

\section{The CBD Cordon}

In response to the extensiveness of damage, cordons were established that restricted access to the CBD, generally in the form of fenced and guarded perimeters. In the aftermath of the September 2010 earthquake, which triggered a declared local state of emergency, a cordon was initially established by local authorities around most of the city center and gradually reduced (Figure 2) until it was fully removed on 10 September 2010. At the time of 
the February 2011 earthquake, barricades remained around individual unreinforced masonry buildings damaged in the September or December earthquakes. These barricades had created significant disruption to local businesses (Kachali et al., 2012). The February earthquake triggered a national state of emergency and saw a cordon established around the whole of the CBD area under the authority of the National Controller. At the end of the state of emergency in April 2011, control of the cordon was transferred to CERA. By July 2011, the CBD cordon had been reduced to about half its original size; subsequent reductions have been quite limited. Figure 2 shows the extent of the CBD cordon at various timeframes from September 2010 through May 2012, at which time approximately 23 blocks remained cordoned.

The cordon was justified to the public on the basis of safety, and indeed, the establishment of the cordon was universally considered a good decision among those interviewed for this study. Barricades around individual unrepaired buildings damaged in September and December ensured that previously damaged structures and adjacent public spaces were vacant in February, potentially saving hundreds of lives in the latter event (Ingham, 2011). According to the National Controller,

Public safety was the driver behind maintaining the cordon. Once the initial response made by members of the public had passed, it was still about public safety, but it was the safety of search and rescue, and emergency services. The thinking then went to opening up areas as much as possible, but still holding a tight cordon so that the "making safe" operations could go on unimpeded. I am adamant that the decision to hold the cordon was right. How on earth could you stand in front of a television camera and say sorry that a couple of guys got cleaned-out by a falling parapet in an aftershock, if they were members of the public? (J. Hamilton, interview, May 11, 2012)

Although less well-publicized, management of the disaster scene, including facilitating search-and-rescue and building assessments, and keeping out curious onlookers, was also an important rationale. It should be noted that area cordoning had some precedent in the 1989 Newcastle, Australia, and 2007 Gisborne, New Zealand, earthquakes where streets were temporarily closed due to building damage (Brunsdon, 2010).

Nonetheless, undertaking such an extreme measure requires considering multiple pressures, from engineering assessments regarding public safety to political factors and the interests of businesses in the CBD. Notably, in the 26 December 2010 aftershock which resulted in damage to many URM buildings in the CBD (Moon et al. 2014), decision-makers in the local government decided not to declare a state of emergency, despite a 
recommendation from emergency management personnel and engineers to do so. Instead, in view of the importance of keeping the CBD open during the busiest shopping season of the year, buildings were rapidly shored up to allow streets to be accessible. ${ }^{5}$

With the frequent aftershocks and pressures to reopen the cordon after the February earthquake, Christchurch City Council (CCC) set up the Indicator Buildings program to help provide decision-makers with some objective basis for determining when re-inspection of damaged buildings might be warranted, following a significant aftershock. The Indicator Buildings program, in which a strategically selected set of representative structures were systematically monitored for incremental damage following significant aftershocks, did lead to the decision in the June 2011 aftershock to re-cordon a broad area of the CBD for 4 5 days, during which time only a small team of engineers were allowed access to conduct safety inspections. This streamlined approach was very efficient and helpful in reassuring the public. It was feasible because by this time, a core team of engineers had already developed familiarity with the buildings in the CBD, having inspected them multiple times.

The impact of the cordon was primarily one of access and oversight. Initially, decisions related to management of the cordon were heavily influenced by technical considerations. Within the cordon, there was greater freedom for construction activities to proceed; for example, permitting requirements were relaxed, and setting up heavy equipment for demolitions did not require the kind of traffic management planning that would have been needed for buildings outside the cordon. Reducing normal bureaucratic processes for buildings inside the cordon enabled dangerous structures to be handled more expeditiously and circumvented normal procedures of working with heritage buildings. The cordon also allowed greater oversight (by CERA); for example, to ensure that all demolition teams were sufficiently qualified (there being a limited number of experienced demolition companies in New Zealand for a disaster of this size).

\footnotetext{
${ }^{5}$ From an engineering response standpoint, the lack of a formal declaration of a state of emergency had important implications. There were fewer resources for building assessments, and engineers were not protected by engineering indemnity for assessments made during a state of emergency. Moreover, in New Zealand, building safety evaluations using red, yellow and green placards (similar to ATC-20 in the U.S.) can only be used during a state of emergency; hence, after the 26 December earthquake, the City was forced to use "dangerous building" designations to identify damaged buildings. This scheme does not capture the range of damage states expected after an earthquake and forces lightly damaged buildings to be either conservatively labeled as "dangerous" or not labeled at all. Moreover, the "dangerous building" designations remain on the title for the building even after the condition has been corrected, potentially impacting the value of the property.
} 
Access was heavily restricted due to safety concerns. Business owners were allowed into their buildings in the cordon area on very restrictive terms and only when accompanied by an engineer and safety personnel (Stevenson et al, 2011a). Civil Defence, and later CERA, were subject to substantial pressure to reduce the cordon quickly in the first $3 \sim 4$ months. Even so, pressures pertained more to the terms of access than to the existence of the cordon itself. The tight control over cordon access caused considerable stress to residents and businesses that were unable to retrieve their possessions, and resulted in many local people and businesses feeling excluded from their city center.

Decisions to take buildings and city blocks out of the cordoned area were made on the basis of safety and degree of damage; however, the prioritization of these cordon reduction decisions were influenced in part by considerations of societal need and commercial issues. For example, early on in the emergency, concerted efforts were made to get a major grocery store out of the cordon so that residents could purchase necessary supplies. The southern portion of the original cordon was prioritized for business resumption reasons, and the hospital and medical specialists were also given priority. CERA later worked with business groups to facilitate the strategic location of a temporary shopping center, the Re:Start mall, which was built out of converted shipping containers just outside the cordon.

While pressure to reduce the cordon was initially strong, it tapered off particularly following the June 13, 2011 aftershocks, which demonstrated to many people the cordon's importance. In those aftershocks, several safety inspection engineers and construction-related personnel were fortunate to escape injury or death while working inside the cordon. Concerns regarding buildings being inside the cordon have reportedly abated. Indeed, some owners and occupants have requested that their buildings be allowed to remain inside the cordon in order to facilitate repairs or demolitions. The reduced concern is in part due to public acceptance over time, completion of salvaging what was possible, the success of businesses in relocating outside of the central city, and the higher insurance coverage of buildings in the central core (see also CERA, 2012a).

The significance of the cordon has probably been magnified by some unique powers legislated to CERA by the CER Act (Parliament of New Zealand, 2011). In particular, CERA has the power to decide which buildings will need to be demolished; owners do not have a right of appeal. In practice, CERA has been requiring building owners to come up with a demolition plan within 10 days of being notified. CERA also has the ability to act as a 
contractor to facilitate the demolitions. (Building owners are given the choice of arranging for their own contractors to demolish a building or allowing CERA to manage and undertake the effort, and to provide the owner with a clean site and a bill at the end of the process. The option to let CERA handle the demolition is reportedly a benefit to smaller owners who do not have the means, know-how, or negotiating power to make their own arrangements in the post-disaster climate.) In cases of buildings identified for demolition whose owners did not respond, or whose insurers refused to pay out, CERA has stepped in and bankrolled the demolition. These unique powers may have been a lesson learned from the September earthquake: it took 6 weeks before demolition could proceed on one heavily damaged 6storey URM building, which disrupted numerous neighboring buildings located in its potential collapse shadow. CERA's unique powers have likely helped to accelerate the pace of demolitions in the CBD. Indeed, over a year after the earthquake, the central city resembles a very large demolition site (Figure 3).

\section{IMPACTS OF THE CORDON}

\section{Short-term impacts}

Because no businesses can operate within the cordon, in the short-term, the cordon has caused complete dislocation of businesses in a large portion of the Christchurch CBD. ${ }^{6}$ This scale of earthquake-induced business dislocation in a major urban area is unprecedented in developed countries. Had the cordon not been established, it is debatable whether or not businesses in functional buildings in the CBD could have continued to operate amidst the extensive damage. One benefit of the cordon was the elimination of immediate uncertainty, in the sense that businesses in the CBD knew they would need to relocate, although the length of time the cordon was expected to be in place has not been communicated to the public.

The majority of businesses displaced from the CBD continue to operate with $54 \%$ of CBD businesses closed temporarily and 31\% permanently (Stevenson et al. 2012; see also Stevenson et al. 2014). Many had to lease space and relocate to places that may not have been ideal for their needs. Landlords who rented out suburban commercial space soon began

\footnotetext{
${ }^{6}$ In the September 2010 earthquake where the cordon was less extensive and enduring, a business survey by | Stevenson et al. (2011 $\underline{b}$ ) also found that CBD location was one of the most important factors influencing business disruption. In some cases, buildings in the CBD had been declared unsafe because of proximity to other unsafe structures, rather than because of direct damage. Businesses in the CBD found neighboring damage and inability to access their site to be more disruptive than actual damage to their own structure.
} 
to charge higher rents than pre-disaster and require longer, multi-year leases. Even government departments have left the CBD and signed multi-year leases, perhaps unintentionally sending negative signals to the business community. Geographically, businesses have been displaced outwards, with the current urban economic landscape resembling a "donut" with an empty center. One important policy decision that reduced the impact of the cordon on businesses was the Central Government's decision to establish a 6week wage support program for displaced businesses (Hatton et al, 2012). This was instituted in both the September and February events with lobbying from business groups. The program provided badly affected businesses with some immediate cash flow for paying employees and allowed time to make necessary relocation and business resumption decisions. The cordon has also contributed to the loss of housing stock in the area, reportedly with some migration of residents to other New Zealand cities.

In the short term, those who had business interruption insurance may not have been able to receive payouts. Reportedly, many businesses’ policies did not include denial-of-access, so that if their buildings could have been occupied, were it not for the cordon, they would not be eligible for insurance payouts. This illustrates one of many types of insurance-related complexities that involves legal resolution and requires substantial time to evaluate.

\section{Longer-term impacts}

The extent and duration of the CBD cordon raise questions about the long-term viability of the downtown area. Prior to the earthquakes, the CBD as a business district had already been facing strong competition from suburban shopping areas and malls. With CBD businesses having dispersed and suburban development accelerating, some observers have questioned who will inhabit buildings that do get repaired or rebuilt in the CBD. As the cordon has been pulled back, it has been observed that in some areas, economic activity has not returned as quickly. Some business leaders see the changed landscape of downtown as a great opportunity for urban revitalization, but acknowledge that this renewal may be decades in the making.

Many interviewees expressed concerns about capital flight, noting that it is already occurring and that there is a need for confidence-building actions that can retain capital in Christchurch, particularly from foreign owners. Reportedly, to maximize insurance payouts, owners need to build another building; but insurers have not been requiring that insurance payouts for damage be spent on rebuilding in Christchurch. Many building owners have 
reportedly been taking their insurance payouts and investing the capital in other cities, not necessarily in New Zealand.

One factor influencing the long-term economic uncertainty related to whether or not building owners and businesses will be able to get insurance going forward. Insurance companies and their reinsurers suffered significant losses in the Canterbury earthquakes, and are trying to reduce their exposure in the New Zealand market. In Christchurch, the owner of an undamaged building would generally be able to retain insurance coverage on it, albeit with substantially higher premium and deductible than before the earthquakes. The owner of a damaged building, however, would be able to recoup some losses through insurance payouts but will have difficulty obtaining insurance cover going forward. Insurance companies must be able to purchase affordable reinsurance. Part of the issue may be related to the size of the New Zealand market: New Zealand has very few purely domestic insurance companies, so the headquarters of most insurers (and all reinsurers) are offshore. Some believe that this distance may be contributing to the industry's shift toward being overly cautious, to the extent of impeding recovery. According to the manager of the national Natural Hazards Research Platform,

Communicating the level of risk has turned around. After September - even half an hour before the February earthquake - we were saying to people that we're not done with the aftershocks. Now we're telling people not to be too cautious, because life has to carry on. We're trying to re-balance the now very conservative approach of insurers and others, but still convey an appropriate level of uncertainty. (K. Berryman, interview May 9, 2012)

The impact of the CBD cordon on the longer-term viability of the CBD is difficult to separate from that of other key decisions, in particular, the decision within the CER Act (Section 17) to separate recovery planning of the downtown from that of the rest of the region. For approximately the first year after the February earthquake, the Christchurch City Council (CCC) was in charge of recovery planning for the downtown. It launched a very popular "Share an Idea” campaign, and developed a Recovery Plan (CCC, 2011) for the downtown rebuild. Meanwhile, CERA was tasked with guiding all other aspects of recovery planning. Only on April 18, 2012, was the downtown recovery planning integrated organizationally into CERA with the establishment of the Central Christchurch District Unit (CCDU) and its urgent mandate to deliver a reconstruction blueprint for the downtown area within 100 days (CERA, 2012b). Although establishing the CCDU and its mandate were widely seen as very 
important to Christchurch's recovery, several interviewees suggested that the process could have been started a year earlier. Instead of planning for recovery, the focus in the downtown had up until that time been focused on the (arguably easier) task of demolitions, leading to a potential situation where demolitions might be completed but no rebuilding starting due to lack of confidence in the future of the downtown, and uncertainty about future building costs.

Many have suggested that in order for the downtown rebuilding to succeed, the size of the downtown will need to be shrunk considerably and "precincts" or concentrations of a critical mass of business activity clearly and strategically established. Where the CCDU decides to locate key facilities (e.g., convention center) will therefore be important. One challenge will be dealing with existing use rights and small land titles ${ }^{7}$.

\section{Hidden and complex impacts}

The CBD cordon may have contributed to a range of other, less apparent and perhaps unanticipated impacts. Several interviewees suggested that the cordon - in conjunction with other factors mentioned above, such as insurance payout conditions, CERA's role in the demolitions process, the bypassing of normal permitting procedures (e.g., for heritage buildings), and the relatively low returns on investment for building owners in the CBD even before the earthquakes - may have facilitated demolitions that are "convenient" for building owners rather than necessary. That is, some otherwise repairable buildings may have been demolished because the circumstances facilitated it. Thus in the end, more buildings in the cordon area may end up being demolished than would actually have warranted demolition on the basis of earthquake damage alone.

The increased propensity to demolish buildings is related to an overall climate of risk aversion that was mentioned by many of the interviewees. Building owners and engineers have reportedly become more risk averse in Christchurch due not only to continuing aftershocks but also to public policy decisions. The hearings of the Royal Commission (on the building failures that caused loss of life) has had a chilling effect on the engineering profession and is reportedly leading to greater risk aversion in engineering assessments of buildings.

Engineers appear to err on the cautious side than too permissive, because then we have an event, and people's lives could be lost. Building owners

\footnotetext{
${ }^{7}$ During the writing of this paper the CCDU released its recovery plan for Christchurch, and details can be found at www.ccdu.govt.nz
} 
are also being cautious because they don't want to be responsible. Now detailed building engineering evaluation reports are coming in with very low assessments... as low as 3\% for example [of New Building Standard levels], and that building is still standing after a series of major earthquake events! (D. Margetts, interview, May 18, 2012)

At the same time, public policy changes related to building standards and assessment have put pressure on building owners. Parliament's decision in the CER Act to require detailed engineering evaluations has begun to uncover a greater degree of vulnerability in the building stock (and in some buildings, a greater degree of damage) than had hitherto been recognized. The legislation further requires building owners to take action on risky buildings, whereas the NZSEE placard system merely gave the owner a snapshot view of risk and a recommendation. Approximately one-third of the detailed building evaluations as of May 2012 have led to buildings being closed down, including many where businesses had successfully reopened after the February earthquake. For example, the Canterbury Museum, which survived the February earthquake with minor damage and reopened in September 2011, was closed again in April 2012 for safety considerations while "further engineering reports are commissioned and assessed.” (Canterbury Museum 2012)

The extent to which insurance and reinsurance contracts will cover paying for seismic upgrades is unclear and contentious due to changes in the seismic design coefficient after the February earthquake (see Gerstenberger et al. 2014) and changes to the target strengthening levels by CCC after the September earthquake (CCC 2010). As the cost of strengthening buildings increases, more building owners are probably deciding to demolish their buildings, particularly if they have a good insurance policy that will cover it. The relatively low deductibles in many insurance policies may have compounded the situation, where building owners found it preferable to use insurance payouts for building a new structure rather than for restoring a repairable structure in an uncertain real estate market. Building owners' resolve to retain heritage structures has also slowly evaporated with continuing, damaging aftershocks. The overall effect of these multiple, interacting factors and decisions has probably been an acceleration of the process of eliminating the poorer (low seismic resistance) building stock.

The cordon may have affected not only the number of building demolitions, but also how buildings are being demolished, with implications for debris management. The original 
debris management plan involved investing in processing facilities at the landfill (see Brown, 2012), with the expectation that simply dumping debris into old quarry sites would not be acceptable, due to potential contamination of drinking water sources and to the wish to reuse as much material as possible. With the cordoned area serving as a controlled construction zone, however, a range of demolition methods became viable. Pre-sorting by first removing salvageable components (steel and other metals, in particular) appears to be popular and economically advantageous. Concrete crushing, typically not allowed in an urban area, could also be done within the cordon. With the cost of dumping unsorted waste in the landfill being reportedly some 15 times higher than depositing sorted debris in the Port of Lyttelton, building owners are able to take advantage of the cordon conditions to recoup some costs by selling scrap steel and other materials.

A further hidden impact of the cordon, suggested by some interviewees, may be that it led to attention being focused (e.g., by CCC and CERA) on the downtown, at the expense of a coordinated approach to regional recovery planning. This may have delayed attention being paid to some of the residential suburban areas.

\section{CONCLUSIONS}

Fifteen months after the February 2011 earthquake, key informant interviewees identified a number of critical decisions influencing the early recovery of Christchurch. The three most significant decisions were: the early establishment of the recovery agency CERA; the residential zoning and associated Government decision to buy out several thousand homes on the worst liquefaction-affected lands; and the decision to maintain the cordon around the CBD for an extended period of time.

At the time of this research, several key challenges were identified for the recovery. Interviewees often mentioned the risk of capital flight, ongoing insurance-related issues, social dislocation of communities, and the potential impact of building regulation changes on rebuild progress. Interestingly, respondents who were more involved with the decisionmaking generally rated recovery progress more highly than those who were less involved.

Establishing and maintaining the Christchurch CBD cordon constituted one of the most important decisions in government response to the Canterbury earthquake sequence, and one that encapsulated all of the key challenges identified. With some 50,000 central city workers displaced, over 1,100 commercial buildings demolished or slated for demolition, and some 
23 city blocks remaining within the cordon as of this study (15 months after the February 2011 earthquake), the CBD cordon is unprecedented as a post-earthquake response and recovery decision in scale and duration (at least in developed countries). It is likely that in New Zealand, cordoning will be considered a viable approach in future earthquakes. Following the 2009 L'Aquila earthquake, the CBD was cordoned off to the public, and sections of the cordon remain three years later. International observers have noted that Christchurch's building stock bears resemblance to many urban areas in the West Coast of Canada and the U.S. (EERI, 2011). The concentration of highly vulnerable building stock in an older downtown core - a condition that precipitated the damage pattern and need for the Christchurch cordon - is characteristic also of many North American cities. To consider whether such a drastic measure as the cordon may be necessary, feasible, or advantageous in future earthquakes striking other countries, it is useful to reflect on lessons from Christchurch.

Findings from this study suggest several key conclusions related to the CBD cordon. First, the decision to establish the cordon was universally supported (by our interviewees, who represented a broad spectrum of society, from structural engineers to citizen groups); the danger to the public from the high concentration of damaged buildings in a situation of numerous aftershocks was widely acknowledged. Second, criticisms of the cordon pertained mainly to the restrictive terms under which businesses were able to access their property and retrieve records and belongings. Even utilities had difficulties accessing their facilities inside the cordon. These criticisms indicate the importance of planning the details of a potential cordon prior to a disaster, including having a good communications plan, a system for deciding who gets access to the cordoned area and under what circumstances, and importantly, an arrangement for alternate locations to where displaced businesses can relocate. Even naming the area the CBD "red zone" may have exacerbated negative perceptions of the area's viability. Some observers have suggested the need to balance considerations of public safety with those of civil liberties, and allowing the public the option of voluntarily assuming some risk as a condition of relaxing the cordon control, as control that is too rigid can slow down business recovery.

Third, it appears that there was a threshold to losses caused by the cordon that was quite quickly attained. Once the cordon was established, it was clear that businesses would need to relocate, even if their own buildings were undamaged; indeed, the most savvy businesses 
signed new space leases within 2 or 3 weeks of the earthquake. Pressures to rapidly reduce the cordon lasted 3 or 4 months, after which many building owners and even some businesses found it advantageous to remain in the cordon.

Fourth, pre-disaster planning is important. Anecdotally, businesses that were most aggravated by the cordon were also those that were the least prepared. Governments, utilities, and private businesses should ensure that critical facilities are not located in an area that could be cordoned due to extensive damage in the immediate neighborhood.

Fifth, the cordon provided a number of benefits in facilitating recovery, particularly in terms of dealing with physical damage. These include reducing short-term uncertainty for businesses in the CBD, accelerating demolitions, facilitating construction logistics, ensuring that contractors met professional standards, and enabling greater debris sorting and waste management. Moreover, given that the CBD needed to contract in size, the cordon has created an environment that may allow the CBD to shrink in a planned and successful manner, providing the city with the "opportunity” to update/rebuild its aging building stock.

Finally, the losses associated with the cordon are substantial, even though they cannot be attributed to the cordon alone but are intricately related to the level of building damage, its concentration, prior conditions of the CBD, decisions and features of the insurance industry, policy changes associated with building standards and assessments, and other factors. These losses include a high degree of uncertainty regarding the future viability of the downtown urban core. It is unclear, however, the extent to which alternatives to establishing the cordon and how it was maintained were actually feasible in the context of the scale of damage in the February earthquake and the unique nature of the ongoing aftershock sequence occurring in such close proximity to the heavily damaged CBD. For such an event, perhaps the main alternatives pertain to managing the cordon better through pre-disaster planning. Such planning should not be limited to the physical aspects of demolition and reconstruction, but consider the implications for dislocation of businesses and residents, as well as opportunities for spatial and economic restructuring.

For a less destructive event with aftershocks at a greater distance, however, decisionmaking regarding a cordon is perhaps less straightforward and more contentious, requiring a thoughtful balancing of benefits and costs. Notably, following the September earthquake, the cordoning was much less comprehensive than implemented after February. If the event had occurred in the daytime and caused fatalities, the approach may have been more stringent. 
For example, the decision was made in areas such as Colombo Street and Cashel Mall to not cordon off the streets but instead to simply barricade certain buildings, in part due to heritage considerations. These areas later suffered extensive URM damage in the February earthquake and caused sidewalk pedestrian fatalities. But it is unclear if February standards should have been applied in September; if they had (with a wider building “collapse shadow” area subject to closure), this would have caused substantially higher business disruption in the CBD.

These findings suggest some priorities for further study. This paper provides a snapshot of early recovery, 15 months after the February 2011 earthquake. Research, including longitudinal studies, is needed to follow up on findings over the longer term; in particular, concerning the economic viability and recovery of the downtown core. In terms of recovery progress, the preliminary finding that those closer to decision-making rated recovery progress higher should be investigated more closely and verified in other disasters. For recovery planning, findings indicate that other earthquake-prone cities would do well to identify spatial concentrations of highly vulnerable building stock and plan the conditions under which different levels of post-earthquake cordoning might be undertaken.

\section{ACKNOWLEDGMENTS}

Support for the University of British Columbia (UBC) research team was provided by the UBC Martha Piper Research Fund. The Resilient Organisations research team members are funded by the Natural Hazards Research Platform. We gratefully acknowledge the generous cooperation and time provided by the interviewees in this study. 


\section{APPENDIX A. LIST OF STUDY PARTICIPANTS}

\section{Decision Makers}

John Hamilton, National Controller and Director: Ministry of Civil Defence and Emergency Management

Steve McCarthy, Regulatory Services Manager: Christchurch City Council

Roger Sutton, Chief Executive: CERA

Diane Turner, General Manager- Strategy, Planning and Policy: CERA

\section{Decision Implementers}

Kelvin Berryman, Manager: Natural Hazards Research Platform, GNS Science

Paul Campbell, Team Leader Engineers: CERA

Carl Devereux, Lead Engineer, Significant Buildings Unit: CERA

John Hare, Principal Engineering Advisor: CERA; President: Structural Engineering Society NZ

David Hopkins, Consulting Engineer, Wellington. Member of Canterbury Earthquake Recovery Commission

Jan Kupec, Chief Geotechnical Engineer: CERA

Kelvin Newman, Department Manager Building Inspections: Christchurch City Council

Mike Stannard, Chief Engineer: Department of Building and Housing

\section{Business and Community Groups}

Lianne Dalziel, Member of Parliament for Christchurch East

Jeff Field, Registrar: University of Canterbury

Paul Lonsdale, ReStart the Heart Trust Manager \& Manager: Central City Business Association

Dave Margetts, Heritage Advisor Architecture \& Conservation: New Zealand Historic Places Trust

Brian Parker, Communications Manager: CANCERN

Peter Townsend, Chief Executive: Canterbury Employers' Chamber of Commerce John Vargo, Co-leader: Resilient Organisations Research Programme

Francis Wevers, Executive Director: Future Canterbury Network

\section{Insurance}

Hugh Cowan, General Manager Research and Education: EQC

Martin Kreft, Regional Manager: MunichRe 
John Lucas, Insurance Manager: Insurance Council of New Zealand

\section{APPENDIX B. INTERVIEW QUESTIONS}

Interview questions were based on a common template and tailored to particular interviewees' roles and expertise. The template below was for decision-maker interviews.

\section{Part 1: General Questions:}

1. Please briefly describe the responsibilities of your position before and after the February 2011 earthquake. In what ways are/were you involved in the postearthquake response, reconstruction and recovery?

2. In your view, on a scale of 1-7 (where 1=“extremely poorly” and 7=“extremely well”), how well is Christchurch's recovery proceeding?

3. Overall, if you were to pick the three most important decisions influencing the recovery of Christchurch, made since February 2011, what would they be? (Prompts: Example decisions might include: establishing CERA, land buyouts in Eastern Suburbs, not saving the Cathedral, etc.)

\section{Part 2: Specific Questions for Decision Makers}

4. Specifically in terms of [decision area, e.g., the CBD cordon], if you were to pick the three most important government decisions in the recovery of Christchurch, made since February 2011, what would they be? Please tell us a little more about each of these decisions: when they were made; what organization made them; what was the basis for these decisions; if they were guided by any specific pre-planning (from either before the September 2010 earthquake, or the period between September 2010 and February 2011), if the outcomes were as anticipated; what alternatives were considered, etc.

\section{Part 3: Sharing the Christchurch Experience}

This will be a less-structured section to elaborate on some of the key lessons learned in your areas of expertise. Questions in this section might be follow-up questions from the first two parts, but could also include:

5. What do you see as the most important challenges for Christchurch's recovery going forward? 
6. What lessons has this disaster provided in terms of recovery-related decision-making? What lessons would you like to share with decision-makers in other earthquake-prone cities around the world?

\section{REFERENCES}

Applied Technology Council. 1989. ATC-20 Procedures for Post-earthquake Safety Evaluation of Buildings. Redwood City, California: Applied Technology Council.

Brown, C.O. 2012. "Disaster Waste Management: A Systems Approach,” Ph.D. dissertation, Department of Civil and Natural Resources Engineering, University of Canterbury, Christchurch, New Zealand. http://www.resorgs.org.nz/Publications/

Brown, C., E. Seville, and J. Vargo. 2013. "The Role of Insurance in Organisational Recovery Following the 2010 and 2011 Canterbury Earthquakes,” Resilient Organisations Research Report 2013/04. http://www.resorgs.org.nz/Publications/

Brownlee, G., 2012. State of Canterbury earthquake recovery, available at: http://www.beehive.govt.nz/speech/state-canterbury-earthquake-recovery (accessed May 2013).

Brunsdon, D. 2010. "Strong Similarities Between Two Urban Earthquakes: Gisborne 2007 and Newcastle 1989,” pp.66 72 in Shaken Up: Proceedings of a Workshop on Recovery Following the Gisborne Earthquake. Lower Hutt, New Zealand: Opus International Consulting Ltd.

Canterbury Earthquake Recovery Authority (CERA). 2012a. "Cordon helping the rebuild," Earthquake recovery update, Issue 9, April, p.1.

CERA. 2012b. "New unit for the rebuild of Central Christchurch," $<<$ http://cera.govt.nz/news/2012/new-unit-for-the-rebuild-of-central-christchurch-18-april2012>>

Canterbury Museum. 2012. “Temporary Closure of Museum Announced,” media release, April 16.

CATDAT. 2011. “Damaging Earthquakes Database 2011 - The year in review”, Integrated Historical Global Catastrophic Database.

CCC 2010. "Questions \& answers regarding the Earthquake-prone dangerous \& insanitary buildings policy 2010”, Christchurch City Council, $<<\underline{\text { http://www.ccc.govt.nz/thecouncil/policiesreports }}$ strategies/policies/groups/buildingplanning/earthquakepronebuildingspolicyqa.aspx >>

CCC 2011. "Central City Plan: Draft Central City Recovery Plan for Ministerial Approval” Christchurch City Council. $<$ http://resources.ccc.govt.nz/files/CentralCityDecember2011/ FinalDraftPlan/FinaldraftCentralCityPlan.pdf $>>$ 
EERI Newsletter Insert, 2011. "The M 6.3 Christchurch, New Zealand, Earthquake of February 22, 2011”, Earthquake Engineering Research Institute, May 2011.

Gerstenberger M., G. McVerry, D. Rhoades, M. Stirling, 2014. "Engineering Implications of the Time-dependent Canterbury Seismic Hazard Model”, Earthquake Spectra, submitted for review for Canterbury Earthquake Sequence Special Issue.

Hatton, T,. Seville, E., Vargo, J. 2012. "Improving the Resilience of SMEs: Policy and practice in New Zealand.” Resilient Organisations Research Report 2012/12 submitted to APEC. http://www.resorgs.org.nz/Publications/

Ingham, J. 2011. “The performance of unreinforced masonry buildings in the 2010/2011 Canterbury earthquakes,” presentation to Canterbury Earthquake Royal Commission.

The Insurance Council of NZ Inc v Christchurch City Council [2013] NZHC 51.

Kam, W.Y., Pampanin, S., and Elwood, K.J., 2011. "Seismic Performance of Reinforced Concrete Buildings in the 22 February Christchurch Earthquake”, Bulletin of the New Zealand Society of Earthquake Engineering, Vol. 44, No. 4, December 2011.

Kachali H., Stevenson J.R, Whitman Z., Seville E., Vargo J. \& Wilson T. 2012. "Organisational Resilience and Recovery for Canterbury Organisations after the 4 September 2010 Earthquake”, The Australasian Journal of Disaster and Trauma Studies, Vol. 2012-1.

King, A., Middleton, D., Johnston, D., Brown, C. 2014. "The Role of Insurance in the Canterbury Earthquake Sequence Recovery Program", Earthquake Spectra, submitted for review for Canterbury Earthquake Sequence Special Issue.

Moon L., M. Griffith, D. Dizhur, I. Senaldi, G. Magenes, J. Ingham. 2014. "The demise of the URM building stock in the Christchurch CBD” Earthquake Spectra, submitted for review for Canterbury Earthquake Sequence Special Issue.

NZHPT (New Zealand Historic Places Trust). 2012. "Heritage Buildings, Earthquake Strengthening and Damage: The Canterbury Earthquakes September 2010-January 2012,” Report for the Canterbury Earthquakes Royal Commission. Final report, March 8. 194pp.

Parliament of New Zealand. 2011. “Canterbury Earthquake Recovery Act 2011,” Public Act 2011 No.12, 18 April.

Stevenson, J. R., Y. Chang-Richards, D. Conradson, S. Wilkinson, J. Vargo, E. Seville, and D. Brunsdon. 2014. "Networks, Local Connectivity, and Organizational Recovery Trajectories following the Canterbury Earthquake Series,” Earthquake Spectra, submitted for review for Canterbury Earthquake Sequence Special Issue.

Stevenson, J. R., H. Kachali, Z. Whitman, E. Seville, J. Vargo, T. Wilson. 2011a. "Preliminary Observations of the Impacts the 22 February Christchurch Earthquake on Organisations and the 
Economy: A Report from the Field (22 February - 22 March 2011)”, New Zealand Society for Earthquake Engineering Bulletin Vol. 44, No. 2, June 2011, pp.65-76.

Stevenson, J. R., Seville, E., Vargo, J. 2012. “The Canterbury Earthquakes: Challenges and Opportunities for Central Business District Organisations” Resilient Organisations Research Report 2012/04 submitted to APEC. http://www.resorgs.org.nz/Publications/

Stevenson, J., J. Vargo, E. Seville, H. Kachali, A. McNaughton, and F. Powell. 2011b. “The Recovery of Canterbury's Organisations: A comparative analysis of the 4 September 2010, 22 February and 13 June 2011 Earthquakes,” Resilient Organisations Research Report 2011/04. http://www.resorgs.org.nz/Publications/

Taylor, J.E., S.E. Chang, K.J. Elwood, E. Seville, and D. Brunsdon. 2012. "Learning from Christchurch: Technical Decisions and Societal Consequences in Post-Earthquake Recovery," Resilient Organisations Research Report 2012/08. http://www.resorgs.org.nz/Publications/

The Treasury (NZ). Budget Economic and Fiscal Update 2011. In: Rawa TTKK ed.Wellington, NZ 2011: 95-101.

Williams, K., N. Rogers, M. Jacka, S. Wallace, S. van Ballegooy, J. Leeves. 2014. “Coordinating geotechnical responses: Informing Government disaster recovery policy and plans for residential communities” Earthquake Spectra, submitted for review for Canterbury Earthquake Sequence Special Issue. 


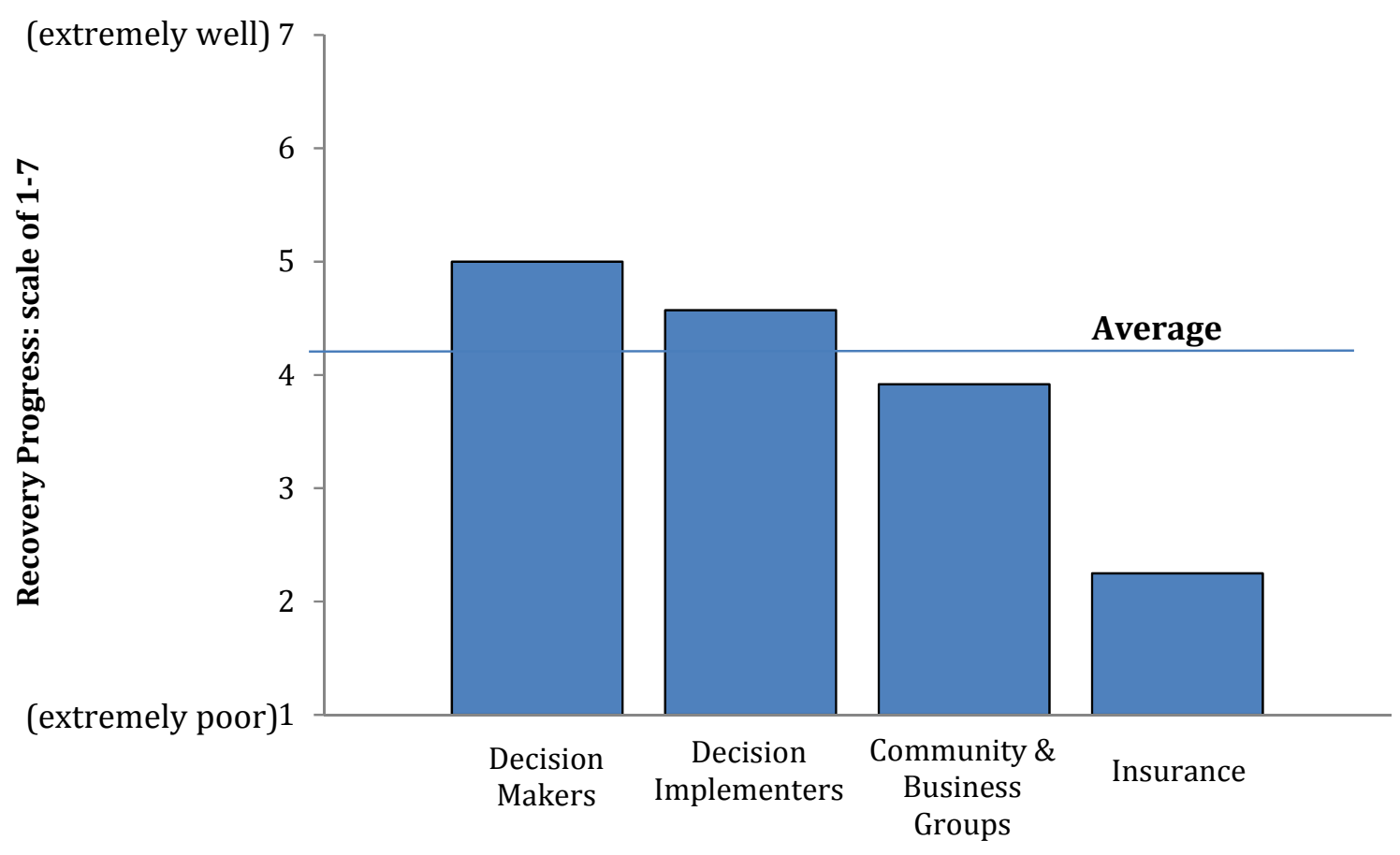

Figure 1. Perspective on Recovery Progress by Proximity to Decision Making 


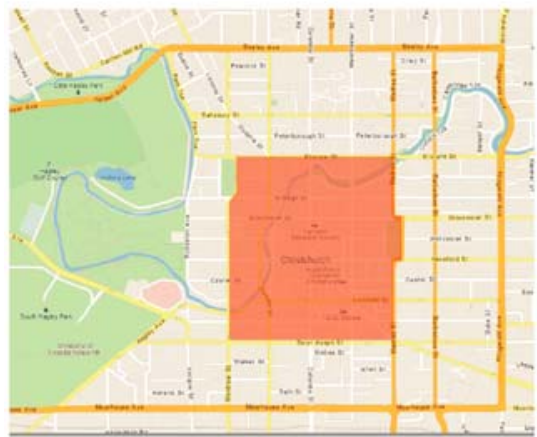

4 September 2010

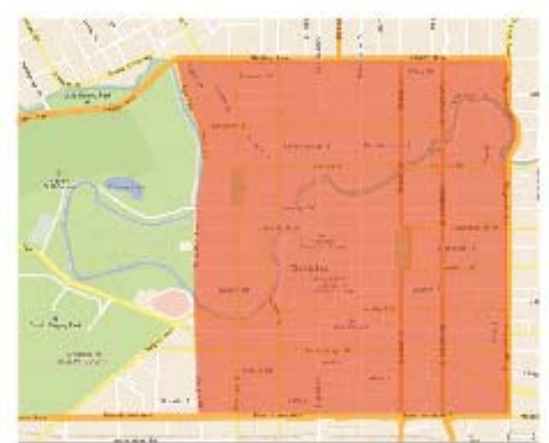

22 February 2011

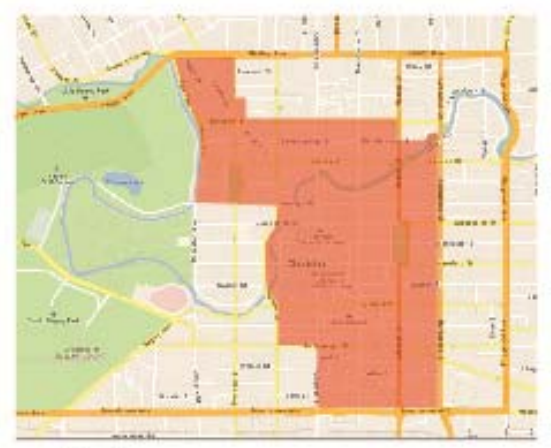

14 March 2011

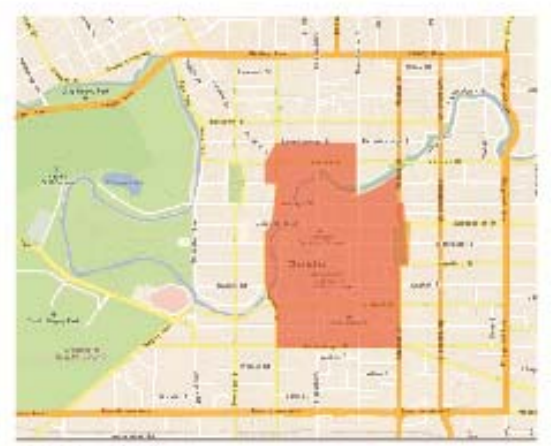

27 May 2011

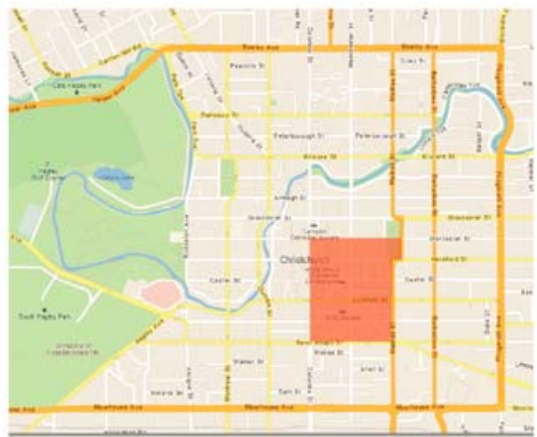

7 September 2010

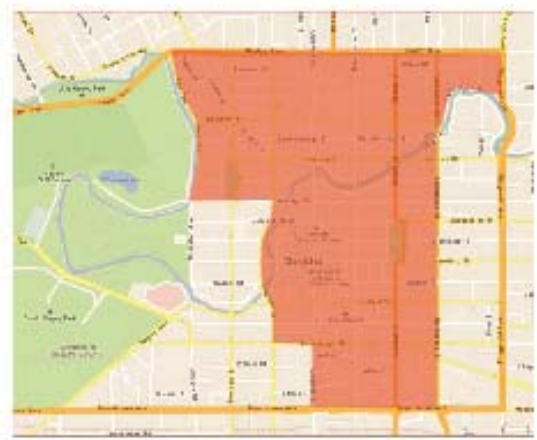

10 March, 2011

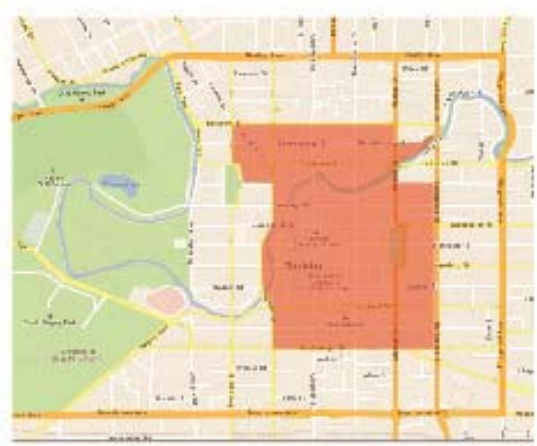

11 April 2011

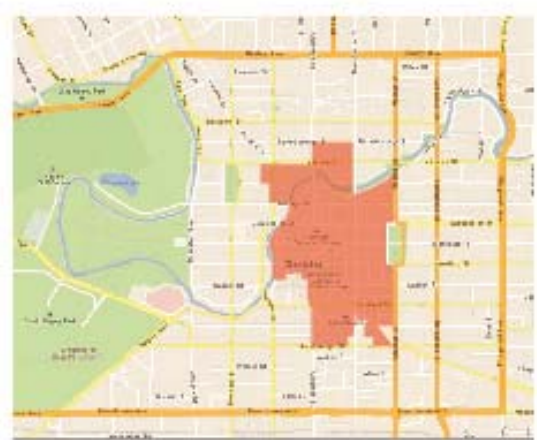

16 March 2012

Figure 2. Extent of Central Business District Cordon, September 2010 May 2012 (Source: after Canterbury Earthquake Recovery Authority, http://cera.govt.nz/maps/cordon-reduction ) 


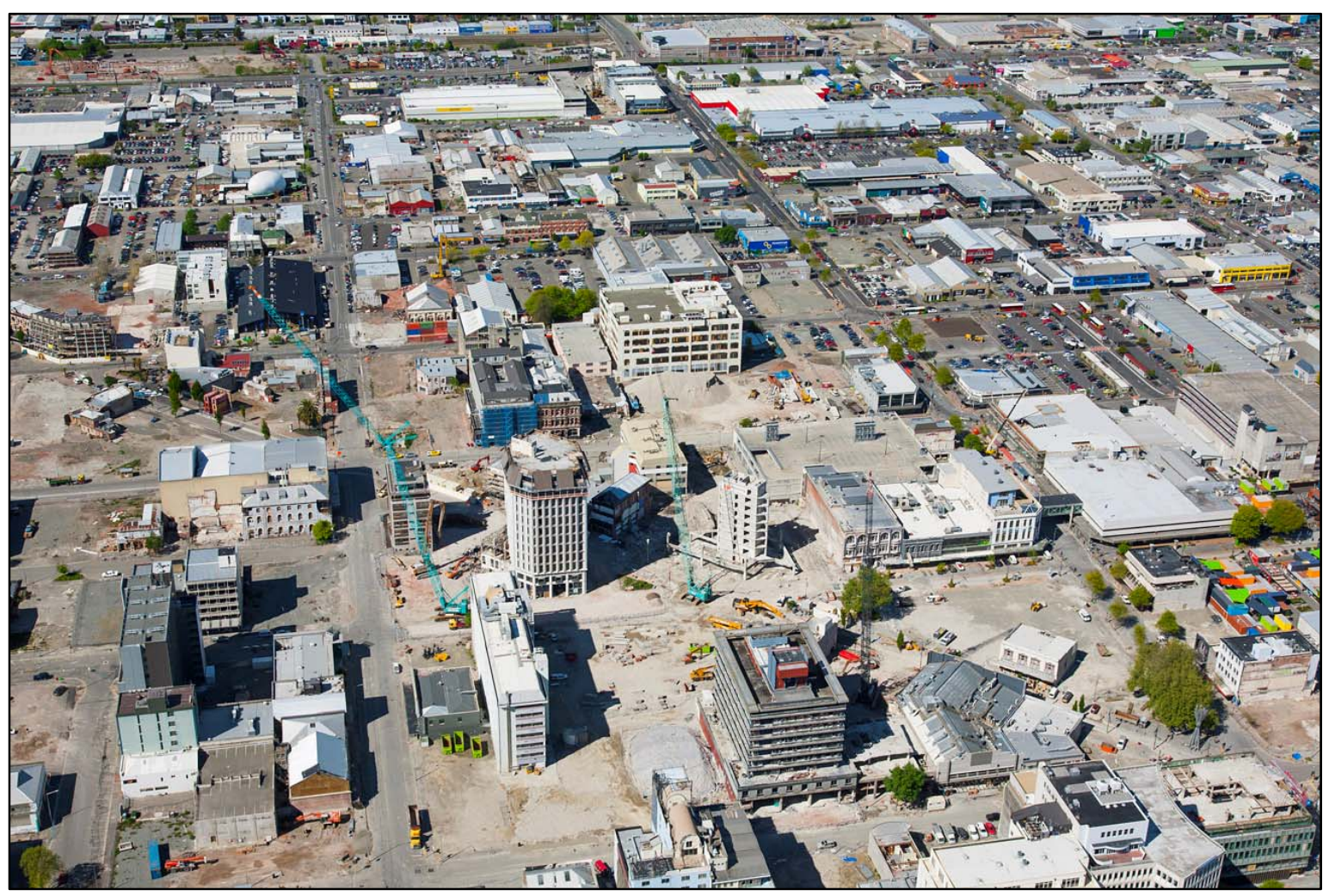

Figure 3. Aerial Photo of Christchurch Central Business District, October 2012 (Source: Canterbury CDEM Group) 